\title{
МЕТОДИ ІДЕНТИФІКАЦІЇ ДИНАМІЧНОЇ МОДЕЛІ РЕАКЦІї СЕРЦЕВО-СУДИННОЇ СИСТЕМИ НА ФІЗИЧНЕ НАВАНТАЖЕННЯ У ХВОРИХ НА ІНФАРКТ МІОКАРДА В ПРОЦЕСІ РЕАБІЛІТАЦІЇ
}

\begin{abstract}
Л. В. Левицька, О. В. Вовкодав ${ }^{1}$
ДВНЗ «Тернопільський державний медичний університет імені І. Я. Горбачевського МОЗ Украӥни»

${ }^{1}$ Тернопільський національний економічний університет

Прогнозування динаміки пульсу та артеріального тиску під дією фрізичного навантаження є ключовим завданням при плануванні процесу реабілітації пацієнта після перенесених серцево-судинних подій, і, в першу чергу, інфраркту міокарда. На сьогоднішній день ії розв'язують емпірично, однак, розроблення адекватної математичної моделі прогнозування основних гемодинамічних показників дозволила б уникнути суб'єктивізму оцінок і підвищити надійність прогнозу, безпеку та есрективність реабілітаційної технології.

3 метою формування судження про зміну стану пацієнта під дією фрізичного навантаження в процесі реабілітації реалізовано систему моделювання рівнів пульсу та артеріального тиску за допомогою пакету прикладних програм для математичного моделювання. ІІї основними підсистемами є обробка та ідентифікація даних, формування прогнозних даних. Для перевірки адекватності побудованої моделі використано засіб перевірки толерантності до фрізичного навантаження. Отримані результати свідчать про адекватність побудованої математичної моделі для аналізованого етапу процесу реабілітації. Максимальний рівень похибок за весь період спостереження склав 9,5 \% щодо пульсу та 5,2 \% щодо артеріального тиску.

Отже, розроблена математична модель динаміки пульсу та артеріального тиску під дією фрізичного навантаження в підгостру фразу реабілітації дозволяє прогнозувати реакцію організму на дозоване фрізичне навантаження. Метод ідентифрікації сукупності диференціальних рівнянь, що моделюють таку динаміку під дією фрізичного навантаження на основі модифікованого градієнтного методу Левенберга-Марквадта, доповненого процедурою вибору початкових значень коефіцієнтів, підтверджує адекватність розробленої математичної моделі.
\end{abstract}

Ключові слова: динамічна модель реакції серцево-судинної системи на фрізичне навантаження, інфраркт міокарда, кардіореабілітація.

\section{METHODS OF IDENTIFICATION OF THE DYNAMIC MODEL OF THE CARDIOVASCULAR SYSTEM REACTION TO PHYSICAL ACTIVITY IN PATIENTS WITH MYOCARDIAL INFARCTION IN THE PROCESS OF REHABILITATION}

\author{
L. V. Levytska, O. V. Vovkodav ${ }^{1}$ \\ SHEE I. Horbachevsky Ternopil State Medical University of the Ministry of Health of Ukraine \\ ${ }^{1}$ Ternopil National Economic University
}

Background. Predicting the dynamics of pulse and blood pressure under physical activity is a key task in planning the patient's rehabilitation process after cardiovascular events and, firstly, myocardial infarction. Nowadays, it is empirically solved, however, the development of an adequate mathematical model for predicting major hemodynamic indicators would avoid the subjectivity of assessments and increase the reliability of the prognosis, safety and effectiveness of rehabilitation technology.

The aim of the study: to develop and identify a dynamic model of the cardiovascular system response to physical activity in patients with myocardial infarction during the rehabilitation process.

Materials and methods. Results. In order to formulate the judgment about changing the patient's condition under the action of physical activity in the process of rehabilitation, a system for modeling the levels of pulse and blood pressure using a package of applied programs for mathematical modeling was implemented. Its main subsystems are processing and data identification, forecasting data generation. To verify the adequacy of the constructed model, a mode to check the tolerance to physical activity was used. Observations were conducted on a group of patients with myocardial infarction of the functional class I-II in the sub acute phase of rehabilitation. The dynamics of the body's response to patients with identical physical activity was recorded at an interval of 3 minutes in the course of a defined phase of the rehabilitation program.

The obtained results testify to the adequacy of the constructed mathematical model for the analyzed stage of the rehabilitation process. The maximum error rate for the entire observation period was $9.5 \%$ for pulse, and $5.2 \%$ for blood pressure.

Conclusions. 1. The mathematical model of the dynamics of pulse and blood pressure under the action of physical activity in the sub-stage of the rehabilitation phase allows predicting the body's response to the graduated exercise.

2. The method of identification of a set of differential equations that simulates the dynamics of pulse and blood pressure under the action of exercise on the basis of the modified gradient Levenberg-Marquardt method, supplemented by the procedure for choosing the initial values of the coefficients, confirms the adequacy of the developed mathematical model.

Key words: dynamic model of the reaction of the cardiovascular system on exercise, myocardial infarction, cardiorehabilitation. 


\title{
МЕТОДЫ ИДЕНТИФИКАЦИИ ДИНАМИЧЕСКОЙ МОДЕЛИ РЕАКЦИИ СЕРДЕЧНО-СОСУДИСТОЙ СИСТЕМЫ НА ФИЗИЧЕСКУЮ НАГРУЗКУ У БОЛЬНЫХ ИНФАРКТОМ МИОКАРДА В ПРОЦЕССЕ РЕАБИЛИТАЦИИ
}

\author{
Л. В. Левицкая, А. В. Вовкодав ${ }^{1}$ \\ ГВУз «Тернопольский государственный медицинский университет \\ имени И. Я. Горбачевского МЗ Украины» \\ ${ }^{1}$ Тернопольский национальный экономический университет
}

\begin{abstract}
Прогнозирование динамики пульса и артериального давления под действием фризической нагрузки является ключевой задачей при планировании процесса реабилитации пациента после перенесенных сердечно-сосудистых заболеваний, и, в первую очередь, инфаркта миокарда. На сегодняшний день ее решают эмпирически, однако, разработка адекватной математической модели прогнозирования основных гемодинамических показателей позволила бы избежать субъективизма оценок и повысить надежность прогноза, безопасность и эффективность реабилитационной технологии.

Целью исследования была разработка и идентисикация динамической модели реакции сердечно-сосудистой системы на фризическую нагрузку у больных инсрарктом миокарда в процессе реабилитации.

С целью формирования суждения об изменении состояния пациента под действием фризической нагрузки в процессе реабилитации реализована система моделирования уровней пульса и артериального давления при помощи пакета прикладных программ для математического моделирования. Ее основными подсистемами является обработка и идентификация данных, формирование прогнозных данных. Для проверки адекватности построенной модели использовано средство проверки толерантности к физической нагрузке. Наблюдения проводились над группой больных инорарктом миокарда I-ІІ фрункционального класса в подострую фразу реабилитации. Динамика реакции организма пациента на идентичную фризическую нагрузку фриксировалась с интервалом 3 минуты в процессе проведения определенного этапа программы реабилитации. Полученные результаты свидетельствуют об адекватности построенной математической модели для рассматриваемого этапа процесса реабилитации. Максимальный уровень ошибок за весь период наблюдения составил 9,5% по пульсу и 5,2% по артериальному давлению.

Таким образом, разработанная математическая модель динамики пульса и артериального давления под действием фризической нагрузки в подострую фразу реабилитации позволяет прогнозировать реакцию организма на дозированную фризическую нагрузку. Метод идентификации совокупности дифференциальных уравнений, моделирующих динамику пульса и артериального давления под действием фризической нагрузки на основе модифицированного градиентного метода Левенберг-Марквадта, дополненного процедурой выбора начальных значений коэффрициентов, подтверждает адекватность разработанной математической модели.
\end{abstract}

Ключевые слова: динамическая модель реакции сердечно-сосудистой системы на фризическую загрузку, инфраркт миокарда, кардиореабилитация.

Вступ. Одним із актуальних прикладних завдань у медичній галузі є прогнозування динаміки пульсу та артеріального тиску (АТ) під дією фізичного навантаження. Таке завдання є ключовим при плануванні процесу реабілітації людини після перенесених захворювань серцево-судинної системи, а особливо інфаркту міокарда (IM). На сьогоднішній день його розв’язують емпірично, однак, використання математичного моделювання дозволило б уникнути суб’єктивізму оцінок та підвищити надійність прогнозу, безпеку та ефективність реабілітаційної технології.

Складність сформульованого завдання спонукає поділити його на два етапи:

1) розробка моделі динаміки пульсу та АТ під дією фізичного навантаження;

2) прогнозування динаміки параметрів попередньої моделі в процесі реалізації програми реабілітації у пацієнтів на IM.

Для обгрунтування теоретичної основи даного дослідження проаналізовано наукові роботи, що присвячені математичному моделюванню серцево-судинної та дихальної систем організму людини під дією фізичного навантаження. Однією 3 перших стала запропонована модель у роботі O. Frank з моделювання серцево-судинної системи за допомогою електричного кола [1], що знайшла своє продовження в ряді робіт інших науковців [2-7]. Недоліками такого підходу є відносно низька точність, складність побудови, ідентифікації та модифікації моделей спеціалістом, не знайомим із теорією електричних кіл. Більш спеціалізованим інструментом моделювання в даному аспекті виступає презентація роботи серцево-судинної системи за допомогою системи звичайних диференціальних рівнянь. Так, робота F. Kappel i співавт. [8] Ірунтується на застосуванні системи диференціальних рівнянь, що моделюють роботу чотирикамерного серця за Grodins, роботу малого та великого кіл кровообігу, лівого та правого шлуночків, барорецепторів. Оскільки модель враховує ефект Старлінга, Bowditchта, саморегуляцію в периферійних областях, її можна використовувати для аналізу кров’яного тиску в мозку та 


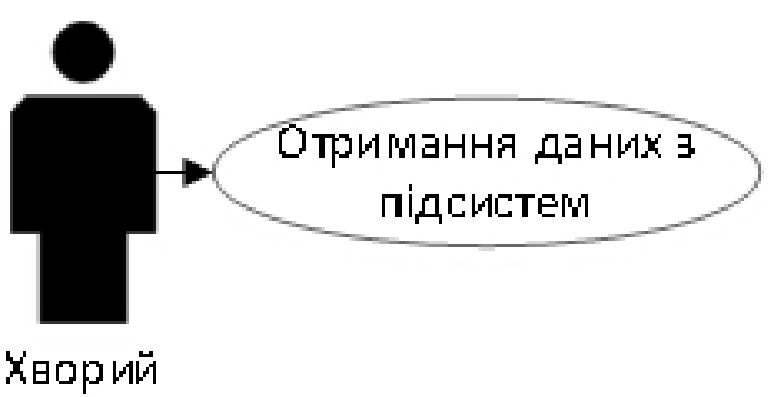

Рис. 1. Отримання вхідних значень для подальшої їх обробки

вимірювання кров’яного тиску під час ортостатичного стресу.

В роботах [9-10], що базуються на дослідженні [8], формується загальна картина поєднання діяльності серцево-судинної та дихальної систем у вигляді одинадцяти диференціальних рівнянь, що представляють: скоротливості лівого та правого шлуночків серця, залежність між серцевим ритмом та скоротливістю, балансові рівняння газів, споживання організмом кисню в процесі навантаження, обмін газів у тканинній частині організму. В роботах [11-13] моделі серцево-судинної та дихальної систем поєднані з кількісним представленням виконуваного фізичного навантаження.

Використання методів, що застосовуються у зазначених роботах [3,4,8-13] для моделювання процесу реабілітації після гострих серцево-судинних захворювань, є громіздкими та занадто складними. Найбільш перспективними методами контролю в реальних програмах відновлення здоров’я після серцево-судинних подій, окрім оцінювання традиційних загальноклінічних показників, $\epsilon$ вимірювання параметрів АТ та пульсу. Такий контроль не вимагає детального аналізу роботи компонентів серцево-судинної системи (ССС), одночасно адекватно відображаючи процеси ї̈ функціонування [14, 15]. Тому, на думку авторів, важливим стає розроблення математичної моделі реакції CCC на фізичне навантаження, що б базувалася на простих у вимірюванні та інтерпретації інтегральних показниках, які відображають системні зміни гемодинаміки в реальних умовах проведення кардіореабілітаційних заходів. Разом із тим, виникає необхідність ідентифікації розробленої моделі та адаптації для конкретних клінічних потреб.

Мета роботи: розробити та ідентифікувати динамічну модель реакції серцево-судинної системи на фізичне навантаження у хворих на інфаркт міокарда в процесі реабілітації.

Матеріал та методи дослідження. Моделювання впливу фізичних навантажень в процесі реабілітації. 3 метою формування судження про зміну стану пацієнта під дією фізичного навантаження в процесі реабілітації реалізовано систему моделювання стану пацієнта за допомогою пакета прикладних програм для математичного моделювання. Ї̈̈ основними підсистемами є обробка та ідентифікація даних, формування прогнозних даних. Принцип роботи можна представити наступними логічними послідовностями функціонування структурних елементів. Оскільки отримана програмна система тісно пов’язана $з$ технічною, то початковим етапом функціонування іï $\epsilon$ отримання показників організму пацієнта (рис. 1).

Структурно-логічний блок обробки та ідентифікації вхідних значень включає в себе процедуру вводу початкових параметрів, підбір початкових значень параметрів впливу пульсу та артеріального тиску на процес до зняття навантаження, процес

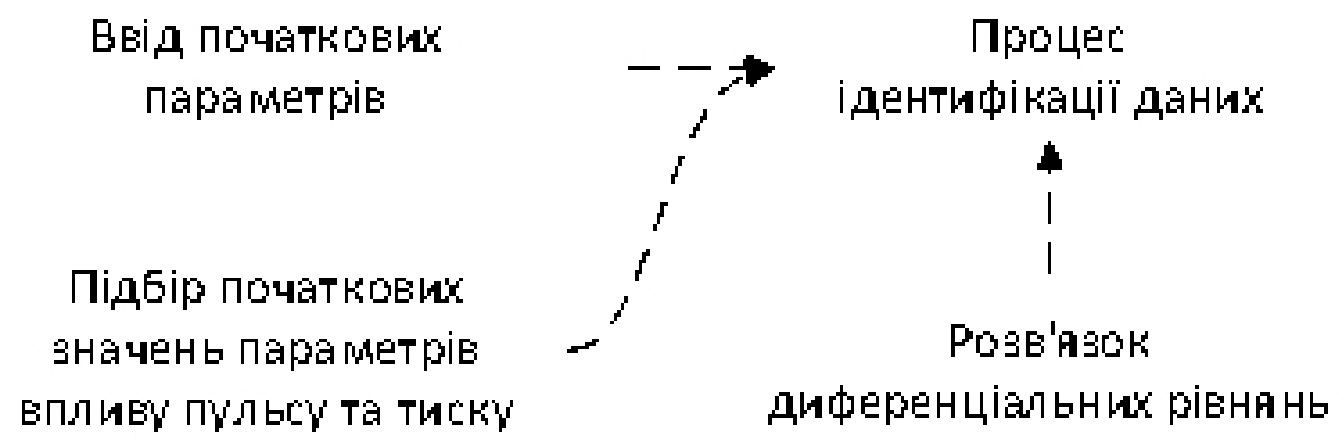

Рис. 2. Підсистема ідентифікації вхідних даних 
ідентифікації даних та розв’язок математичної моделі у вигляді системи диференціальних рівнянь (рис. 2).

При цьому підпрограма ідентифікації організовує циклічний перебір значень деяких параметрів, а значення інших параметрів обчислюються на їх основі. Після встановлення одного набору значень параметрів запускається підпрограма їх уточнення на основі методу Левенберга-Марквардта, що для побудови значень розв'язків при конкретних значеннях параметрів використовує підпрограму розв'язання системи нелінійних рівнянь.

Блок системи, що відповідає функціонуванню підсистеми прогнозування у відповідь на отримані ідентифіковані параметри та значення, в свою чергу, дозволяє формувати поетапний прогноз пульсу та АТ. Оскільки різні етапи процесу реабілітації характеризуються відповідно різними рівнями використовуваного навантаження [15], то процедура отримання прогнозних значень може уточнюватися відповідно до обраного рівня фізичного навантаження. Прогнози здійснюються на основі ідентифікованих значень параметрів моделей у відповідності до аналізованого профілю навантаження, який задається при допомозі таблиць, а потім моделюється за допомогою кусково-кубічного многочлена Ерміта. При врахуванні рівня адаптації організму до субмаксимальних навантажень, на основі початкових спостережених субмаксимальних рівнів пульсу та допустимих значень АТ будується їх прогноз на вибраний момент часу періоду реабілітації. На основі процесу прогнозування модифікуються параметри моделі та здійснюється прогноз реакції організму на навантаження з урахуванням його адаптаційних резервів. Додатковою можливістю цієї компоненти є формування архіву отриманих даних, а також реалізацію на основі відповідного програмного забезпечення можливості графічного виводу результатів для подальшого їх аналізу (рис. 3).

В розробці та коригуванні плану реабілітації пацієнта лікар базується на методичному плані реабілітації, сформованому на основі узагальнення клінічної практики лікувального підрозділу [15]. Однак для точнішої оцінки та прогнозування стану пацієнта в процесі реабілітації використовується підсистема моделювання характеристик серцевосудинної системи. Вона дає змогу передбачити реакцію пацієнта на новий вид фізичного навантаження, а також прогнозувати загальні гемодинамічні закономірності адаптації організму в процесі проведення програми реабілітації.

Завершальним етапом роботи підсистеми прогнозування впливу фізичних навантажень $€$ модифікація існуючого методичного плану для проходження процесу кардіологічної реабілітації на основі отриманих даних та результатів прогнозування.

Результати та їх обговорення. Математична модель та ідентифікація. Клінічна практика виявила два основних етапи функціонування ССС під дією фізичного навантаження: період реакції ССС на навантаження та період відновлення [15]. Період реакції супроводжується підвищенням значень показників пульсу та АТ (в першу чергу, систолічного, що забезпечує інотропну функцію серця) пропорційно до підвищення інтенсивності фізичних навантажень, у той час як період відновлення супроводжується їх поверненням до початкового стану. Загальна структура моделі такого роду представлена на рис. 4 , де $W$-навантаження, $W^{\prime}$ - зміна навантаження, $H, P-$ пульс та

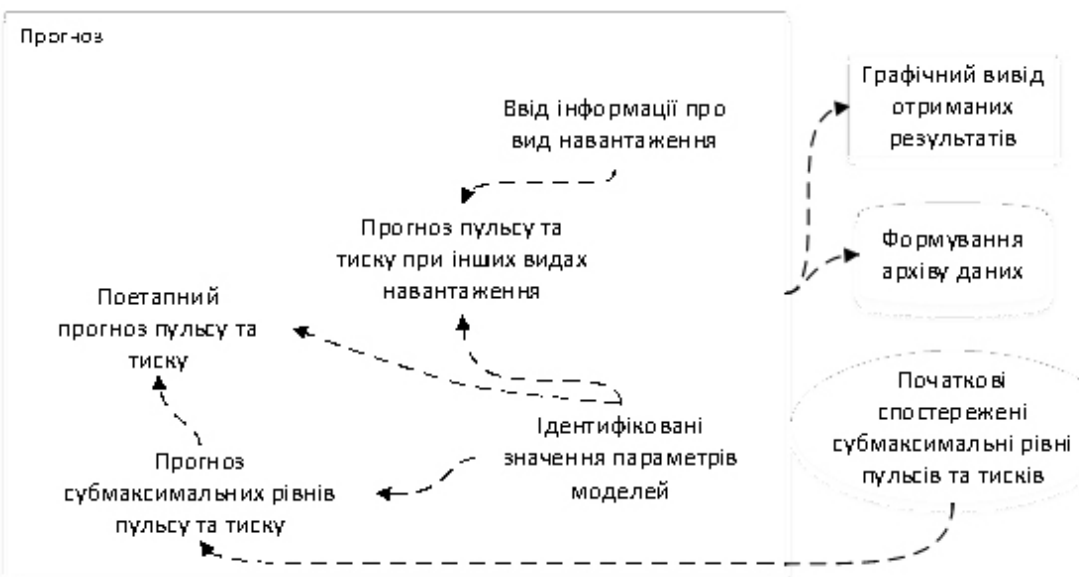

Рис. 3. Підсистема прогнозування на основі вхідних даних 
артеріальний тиск, $H_{i}, P_{0}-$ початкові значення пульсу та артеріального тиску.

Виділити етап реакції організму на фізичне навантаження можна за допомогою функції Міхаеліса-Ментен:

$$
M(t)=\frac{W(t)}{1+W(t)},
$$

що представляє собою гладкий аналог функції Хевісайда. Її значення близькі до 1 при великих обсягах навантаження та прямують до 0 при різкому зменшенні фізичних навантажень. Останнє активізує процес відновлення організму, що виділяється характеристикою $1-M(t)$. Період фази переходу організму від навантаження до відновлення характеризується певною інертністю. Ї̈̈ представляємо запізненням аргументу $\left(t-t_{0}\right)$ у характеристиці процесу відновлення

$$
R(t)=1-M\left(t-t_{0}\right)=1-\frac{W\left(t-t_{0}\right)}{1+W\left(t-t_{0}\right)},
$$

де $t_{0}$ - тривалість переходу від моменту зняття навантаження до моменту активізації процесу відновлення.

Оскільки зміни тиску пропорційні зміні фізичного навантаження $p, h \approx W^{\prime}$ їхня динаміка може бути описана таким завданням Коші для сукупності диференціальних рівнянь:

$$
\begin{aligned}
& h^{\prime}(t)=A_{1} W^{\prime}(t) \frac{W(t)}{(1+W(t))}-\left(1-\frac{W\left(t-t_{0}\right)}{\left(1+W\left(t-t_{0}\right)\right)}\right) A_{2} h^{A_{2}}(t) \\
& p^{\prime}(t)=A_{3} W^{\prime}(t) \frac{W(t)}{(1+W(t))}-\left(1-\frac{W\left(t-t_{0}\right)}{\left(1+W\left(t-t_{0}\right)\right)}\right) A_{4} p^{A_{t}(t)}(7) \\
& h(0)=0 \\
& p(0)=0
\end{aligned}
$$

де $A_{1}, A_{3}$ - показники впливу динаміки навантаження на зміни пульсу та тиску, $A_{2}, A_{4}$ - показники швидкості адаптації до зняття навантаження, $A_{5}, A_{6}$ - коефіцієнти степенів впливу пульсу та тиску на процес адаптації до зняття навантаження, $p, h$ - перевищення значень функціонального рівня значень пульсу та тиску.

Запропонована математична модель вимагає параметричної ідентифікації, що може бути здійснена за допомогою модифікованого градієнтного методу Левенберга-Марквадта. Його реалізація потребує побудови початкового наближення для значень коефіцієнтів моделі. Сам алгоритм ідентифікації розділено на два рівні. На верхньому рівні здійснюється пошук оптимальних значень коефіцієнтів $A_{5}$, $A_{6}$ перебором можливих значень на рівномірних сітках, що покривають деякі емпірично підібрані діапазони. Після вибору значень коефіцієнтів $A_{5}$, $A_{6}$, коефіцієнти $A_{1}-A_{4}$ визначаються методом Левенберга-Марквадта. Їх початкові значення задаються такими співвідношеннями:

$$
\begin{aligned}
& A_{1}=\frac{h^{t}}{W^{\prime}}=\frac{h_{3}-h_{1}}{W_{3}-W_{1}} \\
& A_{2}=\frac{h_{k}-h_{k+2}}{2 \Delta t \cdot h_{k}} \\
& A_{3}=\frac{p^{t}}{W^{t}}=\frac{p_{3}-p_{1}}{W_{3}-W_{1}} \\
& A_{4}=\frac{p_{k}-p_{k+2}}{2 \Delta t \cdot p_{k}},
\end{aligned}
$$

де $t_{k}-$ момент часу зняття навантаження.

Прицьомувраховано,щонапочаткупроцесуреакції $W(t) \approx 1, R\left(t-t_{0}\right) \approx 0, W\left(t_{k}\right) \approx 0, R\left(t_{k}-t_{0}\right) \approx 1$, а на початку процесу відновлення динаміка зміни параметрів близька до лінійної.

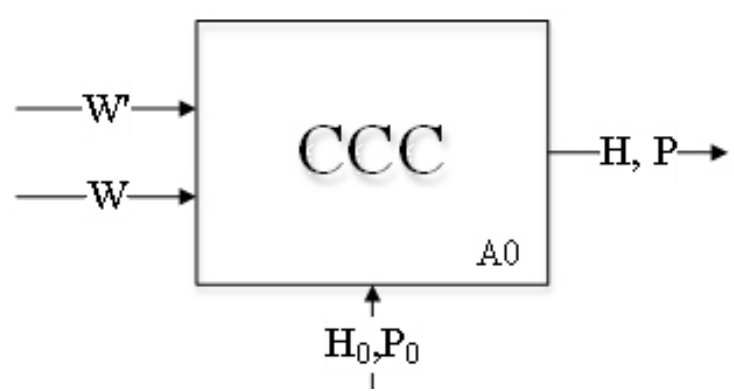

Рис. 4. Параметри, що характеризують ССС під дією фізичного навантаження спрямованих на покращення пульсу та АТ 
Тоді диференціальні рівняння спрощуються, а відповідні співвідношення отримуються з наближення диференціальних операторів різницевими співвідношеннями.

Для перевірки адекватності побудованої моделі використано засіб перевірки толерантності до фізичного навантаження (Ергометр Corival cpet (960900)). Спостереження проводилися за групою хворих на інфаркт міокарда I-II функціонального класу за реабілітаційною класифікацією $[17,18]$, які перебували в підгострій фазі реабілітації. Динаміка реакції організму пацієнтів на ідентичне фізичне навантаження фіксувалося з інтервалом 3 хвилини в процесі проведення визначеного етапу програми реабілітації. В табл. 1 представлено значення еволюції динаміки параметрів серцево-судинної системи спостережуваних пацієнтів.

Таблиця 1

Значення пульсу та АТ отримані в процесі тестування організму хворих на толерантність до навантаження

\begin{tabular}{|l|l|l|l|l|l|l|l|l|l|l|}
\hline W & H1 & H2 & H3 & H4 & H5 & P1 & P2 & P3 & P4 & P5 \\
\hline 0 & 96 & 94 & 83 & 82 & 61 & 158 & 150 & 155 & 140 & 130 \\
\hline 25 & 124 & 115 & 115 & 90 & 81 & 175 & 165 & 170 & 165 & 150 \\
\hline 25 & 120 & 110 & 119 & 88 & 82 & 180 & 175 & 170 & 165 & 150 \\
\hline 50 & 130 & 120 & 125 & 90 & 87 & 200 & 180 & 180 & 180 & 160 \\
\hline 0 & 131 & 122 & 119 & 83 & 68 & 200 & 178 & 170 & 180 & 170 \\
\hline 0 & 117 & 110 & 97 & 75 & 61 & 200 & 175 & 170 & 170 & 172 \\
\hline 0 & 111 & 95 & 89 & 70 & 64 & 180 & 172 & 165 & 170 & 165 \\
\hline 0 & 108 & 92 & 88 & 70 & 60 & 172 & 170 & 165 & 160 & 140 \\
\hline 0 & 104 & 97 & 85 & 71 & 63 & 170 & 165 & 160 & 160 & 138 \\
\hline 0 & 88 & 95 & 82 & 72 & 63 & 170 & 164 & 160 & 155 & 134 \\
\hline 0 & 86 & 91 & 87 & 77 & 62 & 172 & 160 & 156 & 158 & 140 \\
\hline 0 & 86 & 92 & 85 & 74 & 62 & 170 & 145 & 156 & 155 & 135 \\
\hline 0 & 78 & 88 & 81 & 72 & 63 & 150 & 141 & 155 & 150 & 135 \\
\hline 0 & 80 & 88 & 79 & 73 & 62 & 145 & 140 & 150 & 140 & 130 \\
\hline
\end{tabular}

Примітка. W - рівень навантаження, Н1-H5 - значення рівня пульсу 5-ти пацієнтів, виміряного з інтервалом 3 хв, Р1-Р5 - значення рівня артеріального тиску 5-ти пацієнтів, виміряного з інтервалом 3 хв

Надані дані були використані для моделювання показників пульсу та АТ в підгострій фазі реабілітації з оцінкою максимальних відносних похибок.
Значення похибок та ідентифікованих значень коефіцієнтів функції представлено в табл. 2.

Таблиця 2

\section{Значення похибок та ідентифікованих значень коефіцієнтів}

\begin{tabular}{|l|c|c|c|c|l|l|}
\hline № експерименту & A1 & A2 & А3 & А4 & Похибки по пульсу, \% & Похибки по тиску, \% \\
\hline 1 & 0,7656 & 0,0303 & 0,8456 & 0,3704 & 9,53 & 5,16 \\
\hline 2 & 0,6250 & 0,0616 & 0,6426 & 0,3519 & 3,33 & 4,14 \\
\hline 3 & 1,4528 & 0,0471 & 0,4092 & 0,0899 & 2,00 & 2,75 \\
\hline 4 & 0,6027 & 0,0160 & 0,7779 & 0,0701 & 7,92 & 4,93 \\
\hline 5 & 0,9291 & $-0,0056$ & 0,7303 & 0,2704 & 6,09 & 3,93 \\
\hline
\end{tabular}

Примітка. Максимальний рівень похибок за весь період спостереження склав 9,5 \% по пульсу, 5,2 \% по АТ 


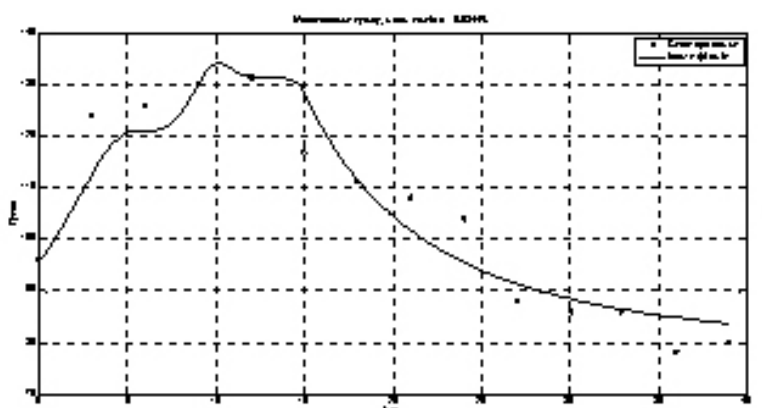

а) пульс

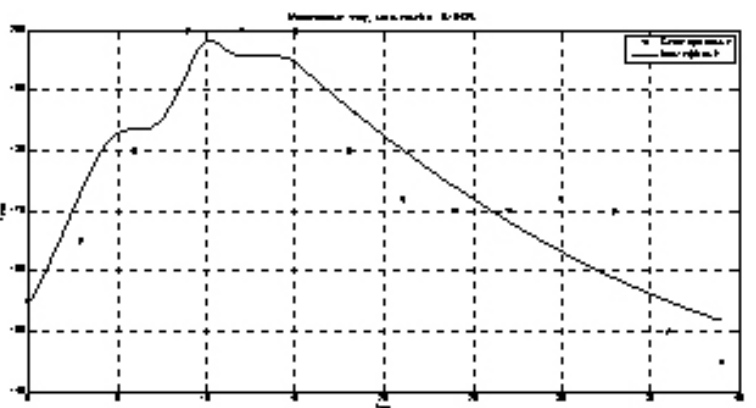

б) $\mathrm{AT}$

Рис. 5. Результати ідентифікації параметрів моделі динаміки пульсу та АТ під дією фізичного навантаження початкового етапу

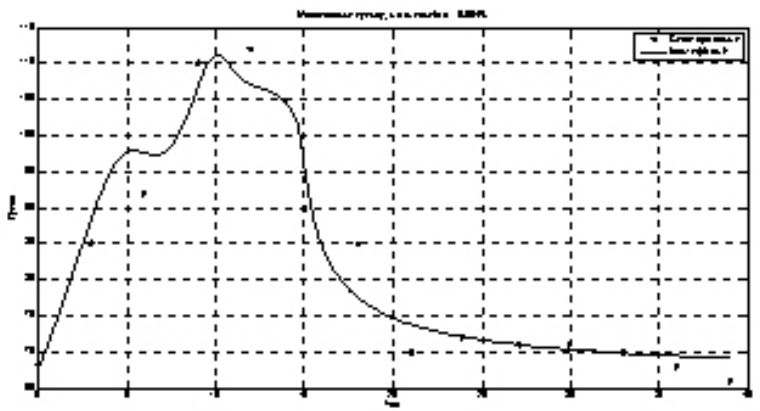

а) ЧСС

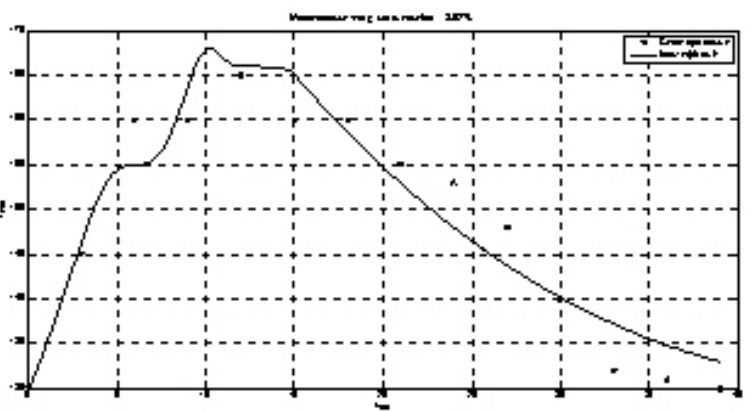

б) AT

Рис. 6. Результати ідентифікації параметрів моделі динаміки пульсу та АТ під дією фізичного навантаження завершального етапу

Отримані результати свідчать про адекватність побудованої математичної моделі для аналізованого етапу процесу реабілітації. Наочно результати ідентифікації згаданої моделі залежності основних показників організму від навантаження початкового та завершального періодів процесу реабілітації представлено на рис. 5, 6.

Аналіз побудованих графіків свідчить про зниження початкових значень пульсу та АТ в результаті програми реабілітації та відновлення показників гемодинаміки після припинення фізичного навантаження.

Висновки. 1. Розроблена математична модель динаміки пульсу та артеріального тиску під дією фізичного навантаження в підгостру фазу реабілітації хворих на інфаркт міокарда дозволяє прогнозувати реакцію організму на дозоване фізичне навантаження.

2. Метод ідентифікації сукупності диференціальних рівнянь, що моделюють динаміку пульсу та артеріального тиску під дією фізичного навантаження на основі модифікованого градієнтного методу Левенберга-Марквадта, доповненого процедурою вибору початкових значень коефіцієнтів, підтверджує адекватність розробленої математичної моделі.

Перспективи подальших досліджень. Апробація математичної моделі динаміки пульсу та артеріального тиску під дією фізичного навантаження в різні фази реабілітаційного процесу у пацієнтів кардіологічного профілю. 


\section{Література.}

1. De Pater L. An electrical analogue of the entire human circulatory system / L. De Pater, J. W. Van den Berg // Med. Electron. Biol. Engineering. - 1964. - Vol. 2. - P. 161-166.

2. Mirzaee M. R. Simulating of Human Cardiovascular System and Blood Vessel Obstruction Using Lumped Method / M. R. Mirzaee, O. Ghasemalizadeh, B. Firoozabadi // World Academy of Science, Engineering and Technology. - 2008. - Vol. 41. - P. 367-374.

3. Perktold K. Computer simulation of local blood flow and vessel mechanics in a compliant carotid artery bifurcation model / K. Perktold, G. Rappitsch // J. Biomech. - 1995. - Vol. 28. - P. 845-856.

4. Kordas M. Analysis of a simplified electrical analog of circulation / M. Kordas // Med Biol Eng. - 1968. - Vol. 6. - P. 109-114.

5. Quarteroni A. Modeling the Cardiovascular System A Mathematical Adventure: Part I. from SIAM News. - Vol. 34, No. 5. - P. 2-3.

6. Van de Vosse, F. N. Mathematical modeling of the cardiovascular system / F. N. Van de Vosse // Journal of Engineering Mathematics. - 2003. - Vol. 47. - P. 175-183.

7. Ottesen J. T. Applied mathematical models in human physiology / J. T. Ottesen, M. S. Olufsen, J. K. Larsen. SIAM, Philadelphia, PA, 2004.

8. Kappel F. A mathematical model for fundamental regulation processes in the cardiovascular system / F. Kappel, R. O. Peer // Journal of Mathematical Biology. - 1993. - Vol. 31, No. 6. - P. 611-631.

9. Timischl S. A global model of the cardiovascular and respiratory system : Candidate's thesis. University of Graz, Institute for Mathematics and Scientic Computing, 1998.

10. Magosso E. A mathematical model of cardiovascular response to dynamic exercise / E. Magosso, A. Felicani, M. Ursino // Proceedings 23rd Annual Conference IEEE/EMBS (Oct. 25-28), 2001, Istanbul, Turkey.

11. Magosso E. Cardiovascular response to dynamic aero bicexercise: amathematical model / E. Magosso, M. Ursino // Med Biol Eng Comput. - 2002. - Vol. 40 (6). - P. 660-674. URL: https://www.ncbi.nlm.nih.gov/ pubmed/12507317.

12. Magosso E. A mathematical model of cardiovascular response to dynamic exercise / E. Magosso, A. Felicani, M. Ursino // Proceedings 23rd Annual Conference IEEE/EMBS (Oct. 25-28), 2001, Istanbul, Turkey.

13. Кюгерян С. Г. Математическая модель сердечно-сосудистой системы организма при физической нагрузке / С. Г. Кюгерян, Т. Г. Петросян // Автоматизация и системы управления. - 2005. - T. LVIII, № 3.

14. Амосов Н. М. Физическая активность и сердце. 2-е изд., перераб. и доп / Н. М. Амосов, Я. А. Бендет. К. : Здоров’я, 1984. - 230 с.

15. Швед М. І. Сучасні технології відновного лікування хворих із гострим коронарним синдромом / M. I. Швед, Л. В. Левицька. - К. : Видавничий дім Медкнига, 2018. - 176 с.
16. Швед М. І. Підходи до оцінки ризиків та функціональних резервів серцево-судинної системи у хворих на інфаркт міокарда з коморбідною патологією, які перебувають у гострому періоді кардіореабілітації / М. І. Швед, Л. В. Левицька // Світ медицини та біології. - 2018. - № 4 (66). - С. 124-130.

17. Вовкодав О. В. Математичні моделі динаміки реабілітації пацієнтів в кардіологічних системах: дис. на здобуття наук. ступеня канд. техн. наук : 01.05.02 - математичне моделювання та обчислювальні методи / Олександр Валерійович Вовкодав. Міністерство освіти і науки України, Національний університет «Львівська політехніка». - Львів, 2015. - 154 c. URL: http://dspace.tneu.edu.ua/jspui/ handle/316497/780.

18. Спосіб прогнозування динаміки пульсу та артеріального тиску в процесі реабілітації хворих на інфаркт міокарда / М. І. Швед, О. В. Вовкодав, Л. В. Левицька, Р. М. Пасічник. Номер патенту: 117742. Опубліковано: 10.07.2017.

\section{References.}

1. De Pater, L., \& Van den Berg, J.W. (1964). An electrical analogue of the entire human circulatory system. Med. Electron. Biol. Engineering.

2. Mirzaee, M.R., Ghasemalizadeh, O., \& Firoozabadi, B. (2008). Simulating of Human Cardiovascular System and Blood Vessel Obstruction Using Lumped Method. World Academy of Science, Engineering and Technology, 41, 367-374.

3. Perktold, K., \& Rappitsch, G. (1995). Computer simulation of local blood flow and vessel mechanics in a compliant carotid artery bifurcation model. J. Biomech., 28, 845-856.

4. Kordas, M. (1968). Analysis of a simplified electrical analog of circulation. Med Biol Eng, 6, 109-114.

5. Quarteroni, A. Modeling the Cardiovascular System A Mathematical Adventure: Part I. from SIAM News, 34, 5, 2-3.

6. Van de Vosse, F.N. (2003). Mathematical modeling of the cardiovascular system. Journal of Engineering Mathematics, 47, 175-183.

7. Ottesen, J.T., Olufsen, M.S., \& Larsen, J.K. (2004). Applied mathematical models in human physiology. SIAM, Philadelphia, PA.

8. Kappel, F., \& Peer, R.O. (1993). A mathematical model for fundamental regulation processes in the cardiovascular system. Journal of Mathematical Biology, 31, 6, 611-631.

9. Timischl, S. (1998). A global model of the cardiovascular and respiratory system. Candidate's thesis. University of Graz, Institute for Mathematics and Scientic Computing.

10. Magosso, E., Felicani, A., \& Ursino, M. (2001). A mathematical model of cardiovascular response to dynamic exercise. 23rd Annual Conference - IEEE/ EMBS, (Oct. 25-28), Istanbul, Turkey. 
11. Magosso, E., \& Ursino, M. (2002). Cardiovascular response to dynamic aero bicexercise: amathematical model. Med Biol Eng Comput., 40 (6), 660-674. Retrieved from: https://www.ncbi.nlm.nih.gov/ pubmed/12507317.

12. Magosso, E., Felicani, A., \& Ursino, M. (2001). A mathematical model of cardiovascular response to dynamic exercise. 23rd Annual Conference - IEEE/ EMBS, (Oct. 25-28), Istanbul, Turkey.

13. Kyugeryan, S.G., \& Petrosyan, T.G. (2005). Matematicheskaya model serdechno-sosudistoy sistemy organizma pri fizicheskoy nagruzke [Mathematical model of the cardiovascular system of the body during exercise]. Avtomatizatsiya i sistemy upravleniya Automation and control systems, LVIII, 3 [in Russian].

14. Amosov, N.M., \& Bendet, Ya.A. (1984). Fizicheskaya aktivnost i serdtse [Physical activity and heart]. The 2nd edn, revised and enlarged. Kyiv: Zdorovia, p. 230 [in Russian].

15. Shved, M.I., Levytska, L.V. (2018). Suchasni tekhnolohii vidnovnoho likuvannia khvorykh iz hostrym koronarnym syndromom [Modern technologies of restorative treatment of patients with acute coronary syndrome]. Kyiv: Vydavnychyi dim Medknyha, p. 176 [in Ukrainian].
16. Shved, M.I., \& Levytska, L.V. 2018. Pidkhody do otsinky ryzykiv ta funktsionalnykh rezerviv sertsevosudynnoi systemy u khvorykh na infarkt miokarda z komorbidnoyu patolohiieiu, yaki perebuvaiut u hostromu periodi kardioreabilitatsii [Approaches to the assessment of the risks and functional reserves of the cardiovascular system in patients with myocardial infarction with comorbid pathology, which are in the acute period of cardio-rehabilitation]. Svit medytsyny ta biolohii - The world of medicine and biology, 4 (66), 124-130 [in Ukrainian].

17. Vovkodav, O.V. (2015). Matematychni modeli dynamiky reabilitatsii patsiientiv v kardiolohichnykh systemakh : matematychne modelyuvannia ta obchysliuvalni metody. Candidate's thesis. Lviv, p. 154. Retrieved from: http://dspace.tneu.edu.ua/jspui/handle/316497/780 [in Ukrainian].

18. Shved, M.I., Vovkodav, O.V., Levytska, L.V., \& Pasichnyk, R.M. (2017). Sposib prohnozuvannia dynamiky pulsu ta arterialnoho tysku v protsesi reabilitatsii khvorykh na infarkt miokarda [A method of forecasting the dynamics of pulse and blood pressure in the process of rehabilitation of patients with myocardial infarction]. Patent number: 117742. Published: 07.10.2017. 